\title{
Health of workers exposed to electric fields
}

\author{
D E BROADBENT,' M H P BROADBENT, ' J C MALE, ${ }^{2}$ AND M R L JONES ${ }^{3}$ \\ From the Department of Experimental Psychology, ${ }^{1}$ University of Oxford, Oxford, OX1 3UD, the Central \\ Electricity Generating Board, ${ }^{2}$ Central Electricity Research Laboratories, Leatherhead, Surrey, and the \\ Central Electricity Generating Board, ${ }^{3}$ SW Region, South Wales District, Swansea SA1 8QL, UK
}

\begin{abstract}
The results of health questionnaire interviews with 390 electrical power transmission and distribution workers, together with long term estimates of their exposure to $50 \mathrm{~Hz}$ electric fields, and short term measurements of the actual exposure for 287 of them are reported. Twenty eight workers received measurable exposures, averaging about $30 \mathrm{kVm}^{-1} \mathrm{~h}$ over the two week measurement period. Estimated exposure rates were considerably greater, but showed fair correlation with the measurements. Although the general level of health was higher than we have found in manual workers in other industries, there were significant differences in the health measures between different categories of job, different parts of the country, and in association with factors such as overtime, working alone, or frequently changing shift. After allowing for the effects of job and location, however, we found no significant correlations of health with either measured or estimated exposure to electric fields.
\end{abstract}

The suggestion that occupational exposure to the electric fields near power transmission plant might have adverse effects on human health first began to be made in the Soviet Union in the late 1960s and early 1970s. Korobkova et al reported that workers in new $500 \mathrm{kV}$ switchyards in the Ukraine complained of several non-specific symptoms, such as tiredness, headache, nausea, and loss of sexual potency, which were attributed to exposure to high electric fields.' ${ }^{1}$ Rules were published in the Soviet Union which put limits on permissible occupational exposure to electric fields greater than $5 \mathrm{kV} / \mathrm{m}$. Subsequent studies of comparable scope in the Westfor example Malboysson, ${ }^{2}$ Roberge, ${ }^{3}$ Stopps et al, ${ }^{4}$ Knave et $a l^{5}$-have found no similar problems associated with electric field exposure in either switchyard workers or linesmen.

Nevertheless, if there is one general criticism that might be made of all studies so far carried out it is that exposures to electric fields have been in varying degrees estimated rather than measured directly. In the present study we have attempted to remedy this deficiency by including individual exposure measurements for the whole study population. Our aim has been to relate these exposure measurements (together with estimates of exposure produced by local management) to several possible indicators of

Received 30 January 1984

Accepted 20 February 1984 ill health as elicited by a questionnaire interview.

The groups chosen for study consisted of the non-clerical staff of three Central Electricity Generating Board (CEGB) transmission districts in the south west of England and South Wales, together with a group of similar staff of the South Wales Electricity Board (SWaEB). The CEGB staff operated and maintained transmission lines and substations running at 132,275 , and $400 \mathrm{kV}$. The SWaEB staff worked with distribution systems running at $11,33,66$, and $132 \mathrm{kV}$; the geographical area they covered overlapped with that of CEGB South Wales district. From the nature of their duties, it was expected that the CEGB groups were more likely to be exposed to high electric fields than the SWaEB group.

From a general occupational health point of view, the interview results contain much interesting material, particularly on the health differences between different jobs. In the present report, however, we concentrate on the relationships with exposure to electric fields.

\section{Methods and measurements}

For a two week period, closely preceding his questionnaire interview, each subject wore a simple single channel electrochemical exposure meter strapped to his upper arm. On interrogation at the end of the period, it gave a single measure of integrated exposure to all field strengths above about 
360 volts per metre. Sometime earlier, estimates had been made of the percentage of his working time that the man had spent exposed to low, medium, and high field strengths during the past six months and also during the past 15 years.

The interview questions, about 150 in all, included several directly related to symptoms of the type originally reported from the Soviet Union. They were administered by CEGB nurses, specially trained in a standard interview technique and methods of coding the responses.

The interviews and exposure assessments were carried out quite separately so that people collecting one set of data were prevented from being influenced by a knowledge of the other set. The two separately coded data sets were brought together for analysis at Oxford. This procedure incidentally helped to maintain confidentiality of the information and was known to the respondents.

Within the four districts studied 540 men were identified as potential subjects. Of these, 484 agreed to participate, although in several cases the interview or exposure assessments were unsatisfactory for one reason or another. A systematic bias towards low ill health scores was apparent in the questionnaire responses elicited by one of the nurses and it was thought safer to omit all 65 subjects interviewed by her from the analysis. (Interviewer differences were checked by ensuring that two nurses operated in each district and one of the nurses operated in all districts.) In 18 cases exposure measurements were not obtained and in two cases the measurements were rejected as faulty at an early stage. (In one case the meter was faulty and in the other the value was suspiciously high (more than $1000 \mathrm{kVm}^{-1} \mathrm{~h}$ ) and the man's work history over the measurement period made it unlikely that he had been appreciably exposed.) For a further nine subjects exposure estimates were not obtained.

As many as possible of the meters ( 72 of 92 originally deployed) were recovered at the end of the study. Several had faults that had not been detected at the outset. If this was the case or if the meter could not be recovered, the exposure measurements were rejected: 112 measurements were thus lost. Analyses have been conducted including these doubtful measurements, but they do not alter the conclusions given below.

There are no other lost data. With regard to exposure measurements, therefore, the present findings are based on 287 subjects; with regard to exposure estimates, they are based on 390 subjects and, for health interviews alone, on 399 subjects. Jobs were classified into five main categories; fitters, linesmen, engineers, substation attendants, and miscellaneous others. ${ }^{*}$ Table 1 gives the distribution of subjects between the various jobs and districts.

\section{Exposure assessments}

\section{MEASUREMENT TECHNIQUE}

In this context the term "exposure" has no generally agreed definition. Nevertheless, in their study of Ontario Hydro transmission workers, Stopps and Janischewskj used a parameter that combined field strength ( $E)$ and duration ( $t)$ in the simplest possible way-that is, exposure $=\int E \mathrm{dt}^{4}{ }^{4} \mathrm{~A}$ similar parameter had been suggested by Deno in conjunction with his design for an electrochemical "dosimeter." Whereas this method of quantifying exposure is convenient, it should be emphasised that there is little evidence for supposing that it has any significance in terms of biological effects-for ? example, that long exposure to low fields is in any way equivalent to short exposure to high fields.

*Substation attendants: take instrument readings, operate switches and other equipment about a substation. Linesmen: repair and maintain overhead power lines; (no live line work is undertaken in the United Kingdom at voltages of $132 \mathrm{kV}$ or more). Fitters: repair and maintain equipment and plant in substations. Engineers: have a mainly supervisory role, partly office based and including on site inspections of lines and substations. Others: include messengers, drivers, painters, etc, who may on occasion spend time near energised equipment.

Table 1 Distribution between the various jobs and districts of subjects with measured or estimated exposure to electric fields or both

\begin{tabular}{|c|c|c|c|c|c|c|c|}
\hline District & & $\begin{array}{l}\text { Substation } \\
\text { attendants }\end{array}$ & Fitters & Engineers & Linesmen & Others & Totals \\
\hline South Wales & $\begin{array}{l}\text { Measured } \\
\text { Estimated }\end{array}$ & $\begin{array}{l}6 \\
9\end{array}$ & $\begin{array}{l}10 \\
21\end{array}$ & $\begin{array}{l}15 \\
25\end{array}$ & $\begin{array}{r}5 \\
11\end{array}$ & $\begin{array}{l}14 \\
22\end{array}$ & $\begin{array}{l}50 \\
88\end{array}$ \\
\hline $\begin{array}{l}\text { Severn and } \\
\text { Thames }\end{array}$ & $\begin{array}{l}\text { Measured } \\
\text { Estimated }\end{array}$ & $\begin{array}{l}26 \\
28\end{array}$ & $\begin{array}{l}35 \\
39\end{array}$ & $\begin{array}{l}32 \\
36\end{array}$ & $\begin{array}{r}9 \\
15\end{array}$ & $\begin{array}{l}14 \\
22\end{array}$ & $\begin{array}{l}116 \\
140\end{array}$ \\
\hline SWaEB & $\begin{array}{l}\text { Measured } \\
\text { Estimated }\end{array}$ & $\begin{array}{l}4 \\
5\end{array}$ & $\begin{array}{l}39 \\
51\end{array}$ & $\begin{array}{l}16 \\
21\end{array}$ & $\begin{array}{l}16 \\
22\end{array}$ & $\begin{array}{l}46 \\
63\end{array}$ & $\begin{array}{l}121 \\
162\end{array}$ \\
\hline Totals & $\begin{array}{l}\text { Measured } \\
\text { Estimated }\end{array}$ & $\begin{array}{l}36 \\
42\end{array}$ & $\begin{array}{r}84 \\
111\end{array}$ & $\begin{array}{l}63 \\
82\end{array}$ & $\begin{array}{l}30 \\
48\end{array}$ & $\begin{array}{r}74 \\
107\end{array}$ & $\begin{array}{l}287 \\
390\end{array}$ \\
\hline
\end{tabular}

Note that the proportions in different jobs differ significantly between the districts. CEGB Severn and Thames districts have been amalgamated for the analysis. 
We used a miniature version of the Deno dosimeter in the present study. It weighs about $15 \mathrm{~g}$ and comprises two parallel copper plates, $44 \mathrm{~mm}$ square and $10 \mathrm{~mm}$ apart mounted in the base and lid of a plastic box about $50 \mathrm{~mm}$ square and $13 \mathrm{~mm}$ deep. Displacement current flowing between the plates is full wave rectified by a passive diode bridge and passed through an electrochemical storage cell (Plessey E-cell). During exposure, silver is plated on to a central gold electrode in the cell in proportion to the charge passing. Read out is accomplished by passing a controlled current for a measured time in the reverse direction until removal of all the plated silver is signalled by a sharp rise in voltage across the cell.

Laboratory tests established that the meters did not respond to field strengths less than about 150 $\mathrm{V} / \mathrm{m}$, this field being necessary to establish the forward voltage drop across the diode bridge. For greater field strengths, the response was linear at 34 $\mu \mathrm{C} / \mathrm{kVm}^{-1} \mathrm{~h}^{*}$ with a standard error of about $5 \%$.

In use, the meter was worn facing outwards on the subject's upper arm, held outside the normal clothing in an armband sleeve incorporating an inside facing layer of conducting fabric to improve capacitive coupling to the subject's body. When worn in this way by different subjects standing upright in a uniform vertical electric field, the meters gave an average response of $82 \mu \mathrm{C} / \mathrm{kVm}^{-1} \mathrm{~h}$, corresponding to an effective field enhancement factor (the factor by which the strength of the local field near the body surface exceeds its unperturbed value) of about $2 \cdot 4$.

Individual subjects of different height and build, however, gave mean responses up to $20 \%$ above or below this average, and individual readings were themselves subject to considerable variability on different occasions, due partly to differences in clothing and footwear and partly to the precise way the armband was worn and the way the meter was positioned within it. For a given subject standing upright, the standard deviation of calibration readings taken under similar exposure conditions was about $20 \%$. For practical reasons, however, the overall average response of $82 \mu \mathrm{C} / \mathrm{kVm}^{-1}$ h quoted above was assumed throughout the survey, with no allowance for individual subject variations or postures or for possible non-uniformity of the actual field configurations that might have been encountered.

As a result of polarisation effects within the electrochemical cells, the minimum "zero-exposure" read out was about $150 \mu \mathrm{C}$ and over a two week period this figure tended to drift upwards, although the "noise" thus introduced was effectively non-

*Microcoulomb per kilovolt per metre hour. additive in the presence of moderate genuine exposure. Read outs from a group of 64 meters, left for two weeks in zero electric field in a metal enclosure, ranged from $170 \mu \mathrm{C}$ to $500 \mu \mathrm{C}$ and closely followed a $\log$ /normal statistical distribution. Assuming this distribution to hold, a value of $540 \mu \mathrm{C}$ (three standard deviations above the mean and therefore likely to occur less than once during the whole survey) was adopted as the threshold for reliable detection of exposure. The corresponding exposure value is 6.6 $\mathrm{kVm}^{-1} \mathrm{~h}^{*}$

\section{MEASUREMENT RESULTS}

The most striking feature of the measured exposures is their generally low level compared with prior expectations or the estimates. Of the 287 subjects included in the analysis, only 28 received exposures above the $6.6 \mathrm{kVm}^{-1} \mathrm{~h}$ threshold of reliable detection. These individuals are listed in table 2.

The most heavily exposed group were in the CEGB South Wales district, with 13 subjects out of 50 recording above the threshold and the largest exposure being $242.6 \mathrm{kVm}^{-1} \mathrm{~h}$. The least exposed group were the SWaEB distribution staff, also in South Wales but working exclusively with lower voltage systems (132 kV and below). They registered exposure in only two cases out of 121 , and the most exposed individual recorded only $11.6 \mathrm{kVm}^{-1} \mathrm{~h}$ over the ten working days.

\section{COMPARISON WITH ESTIMATES}

In considering the above results, it comes as no surprise to find that distribution staff (the SWaEB group) were rarely exposed. They had been included in the survey with this expectation. What is surprising is the comparative rarity of exposure among the transmission staff. Of the 166 measurements, only 26 exceeded the detection threshold, their average being $3.19 \mathrm{kVm}^{-1} \mathrm{~h}$ per working day.

The exposure estimates made in the present study suggest average exposures considerably greater than those indicated by the measurements. The estimates were made by a senior engineer in each district on the basis of his own records and personal knowledge of the work histories of the men concerned. They were guided by electric field maps of typical substation and overhead line environments and were made in terms of subjective judgments of the percentage of the man's working time spent in three bands of field strength: $1 \cdot 5-5 \cdot 5,5 \cdot 5-9 \cdot 5$, and $>9 \cdot 5 \mathrm{kV} / \mathrm{m}$ for

\footnotetext{
*In an attempt to reduce bias due to noise. 41 of the later measurements were made differentially, with preinjected meters. Their median value was $3.6 \mathrm{kVm}^{-1} \mathrm{~h}$ less than that of the remainder. This difference was added individually to all such differential results below the $6.6 \mathrm{kVm}^{-1} \mathrm{~h}$ threshold before combining them with the general pool for analysis. In only one case did this raise a result from below the threshold to above it.
} 
Table 2 Cases of exposure to $6.6 \mathrm{kVm}^{-1} \mathrm{~h}$ or more over ten working days

\begin{tabular}{|c|c|c|c|}
\hline$J o b$ & District & Main activities/environment & $\begin{array}{l}\text { Exposure } \\
\left(k V m^{-1} \mathrm{~h}\right)\end{array}$ \\
\hline Eng & $\begin{array}{l}\text { S Wales } \\
\text { SWaEB }\end{array}$ & $\begin{array}{l}\text { Power stn, } 275 / 132 \mathrm{kV} \text { substn } \\
132 \mathrm{kV} \text { overhead lines (OHL) }\end{array}$ & $\begin{array}{r}74 \cdot 5 \\
7 \cdot 7\end{array}$ \\
\hline $\mathbf{L}$ & $\begin{array}{l}\text { Thames } \\
\text { Thames } \\
\text { Thames } \\
\text { S Wales } \\
\text { S Wales } \\
\text { SWaEB }\end{array}$ & $\begin{array}{l}\text { Routine maintenance, } 400 \mathrm{kV} \text { OHL } \\
\text { Routine maintenance, } 400 \text { and } 132 \mathrm{kV} \text { OHL } \\
\text { Insulator cleaning, } 400 \mathrm{kV} \text { OHL } \\
\text { Earth wire maintenance, } 275 \mathrm{kV} \text { OHL } \\
\text { Earth wire maintenance, } 275 \mathrm{kV} \text { OHL } \\
\text { Line patrol, } 33 \mathrm{kV} \text { OHL }\end{array}$ & $\begin{array}{r}8 \cdot 2 \\
8 \cdot 7 \\
56 \cdot 8 \\
34 \cdot 1 \\
6 \cdot 8 \\
11 \cdot 6\end{array}$ \\
\hline SSA & $\begin{array}{l}\text { Thames } \\
\text { Severn } \\
\text { S Wales } \\
\text { S Wales } \\
\text { S Wales }\end{array}$ & $\begin{array}{l}400 \mathrm{kV} \text { substn } \\
275 \mathrm{kV} \text { substn } \\
275 \text { and } 132 \mathrm{kV} \text { indoor and outdoor substns } \\
400 \mathrm{kV} \text { substn } \\
400 \mathrm{kV} \text { substn }\end{array}$ & $\begin{array}{r}8 \cdot 3^{*} \\
12 \cdot 1 \\
7 \cdot 3 \\
19 \cdot 3 \\
25 \cdot 0\end{array}$ \\
\hline $\mathbf{F}$ & $\begin{array}{l}\text { Thames } \\
\text { Thames } \\
\text { Thames } \\
\text { Thames } \\
\text { Thames } \\
\text { Thames } \\
\text { Thames } \\
\text { Severn } \\
\text { S Wales } \\
\text { S Wales } \\
\text { S Wales } \\
\text { S Wales }\end{array}$ & $\begin{array}{l}400 \text { and } 275 / 66 \mathrm{kV} \text { substn } \\
\text { Insulator cleaning, } 400 \mathrm{kV} \text { substn } \\
\text { Cct-breaker maintenance, } 275 \mathrm{kV} \text { substn } \\
\text { Construction work and transformer maintenance, } 275 / 66 \mathrm{kV} \text { substn } \\
\text { Cct-breaker maintenance, } 400 \mathrm{kV} \text { substn } \\
\text { Insulator cleaning and general duties, } 400 \mathrm{kV} \text { substn } \\
\text { Scaffolding and compressor maintenance, } 400 \mathrm{kV} \text { substns } \\
\text { Various duties, } 400,275 \text {, and } 132 \mathrm{kV} \text { substns } \\
\text { Busbar maintenance, } 275 \mathrm{kV} \text { indoor substn: cct-breaker maintenance, } 132 \mathrm{kV} \text { substn } \\
\text { Various duties, } 400 \text { and } 132 \mathrm{kV} \text { indoor substns } \\
\text { Wiring modifications, } 275 / 132 \mathrm{kV} \text { substn } \\
\text { Protection tests, } 400 \text { and } 132 \mathrm{kV} \text { indoor substns; cct-breaker tests, } 132 \mathrm{kV} \text { substn }\end{array}$ & $\begin{array}{r}23.7 \\
29.4 \\
7.1 \\
14.0 \\
10.2 \\
31.5 \\
14.9 \\
7.3 \\
15.2 \\
75.6 \\
12.9 \\
242.6\end{array}$ \\
\hline Other & $\begin{array}{l}\text { S Wales } \\
\text { S Wales } \\
\text { S Wales }\end{array}$ & $\begin{array}{l}\text { Foreman: supervising cct-breaker maintenance, } 132 \mathrm{kV} \text { substn } \\
\text { Painter, } 400 \mathrm{kV} \text { substn } \\
\text { Mate, building work, } 400 \mathrm{kV} \text { substn: cct-breaker maintenance, } 275 \mathrm{kV} \text { indoor substn }\end{array}$ & $\begin{array}{l}43 \cdot 4 \\
11 \cdot 5 \\
30 \cdot 1\end{array}$ \\
\hline
\end{tabular}

periods of six months and 15 years before the measurement survey. Averaged results are given in table 3.

Although the average of all 287 meter readings was $6.32 \mathrm{kVm}^{-1} \mathrm{~h}$ over the two week period, the estimates (for 390 subjects) would yield approximate corresponding averages of $79 \mathrm{kVm}^{-1} \mathrm{~h}$ (6 months) and $61 \mathrm{kVm}^{-1} \mathrm{~h}$ (15 years). Nevertheless, despite the quantitative differences, the estimates and measurements do show some correlation with each other, particularly in the medium field ranges (see also table 9).

In studies carried out elsewhere estimated expos- ures for comparable staff have also been rather greater than our measured values. Knave et al in Sweden estimated typical exposures for substation workers on the basis of measurements made with portable multichannel dosimeters. ${ }^{5}$ They concluded that significant periods were spent in fields exceeding $5 \mathrm{kV} / \mathrm{m}$. Although the form of their published data does not allow precise calculation, the figures quoted suggest overall average exposures an order of magnitude greater than those measured in the present study.

On the basis of brief measurements made during live line working, Stopps et al estimated that Ontario

Table 3 Average measurements and estimates of exposure for the whole population and for those with measured exposures above the threshold of reliable detection. (Standard deviations in parentheses)

\begin{tabular}{|c|c|c|c|c|c|c|c|}
\hline & \multirow{3}{*}{$\begin{array}{l}\text { Exposure meter } \\
\text { readings over } \\
2 \text { weeks } \\
\left(\mathrm{kVm}^{-1} \mathrm{~h}\right)\end{array}$} & \multicolumn{6}{|c|}{$\begin{array}{l}\text { Estimated percentage of working time spent in three ranges of field } \\
\text { strength }(\mathrm{kV} / \mathrm{m})\end{array}$} \\
\hline & & \multicolumn{3}{|c|}{ Over past 6 months } & \multicolumn{3}{|c|}{ Over past 15 years } \\
\hline & & $\begin{array}{l}\text { Low } \\
(1 \cdot 5-5 \cdot 5)\end{array}$ & $\underset{(5 \cdot 5-9 \cdot 5)}{\text { Medium }}$ & $\underset{(>9.5)}{\text { High }}$ & $\begin{array}{l}\text { Low } \\
(1 \cdot 5-5 \cdot 5)\end{array}$ & $\underset{(5 \cdot 5-9 \cdot 5)}{\text { Medium }}$ & $\begin{array}{l}\text { High } \\
(>9 \cdot 5)\end{array}$ \\
\hline $\begin{array}{l}\text { Average for whole population ( } 287 \text { for } \\
\text { measurements, } 390 \text { for estimates) } \\
\text { Average for those measured above } \\
6.6 \mathrm{kVm}^{-1} \mathrm{~h} \text { ( } 28 \text { for measurements, } \\
26 \text { for estimates) }\end{array}$ & $\begin{array}{c}6 \cdot 32 \\
(16 \cdot 18) \\
30 \cdot 35 \\
(45 \cdot 83)\end{array}$ & $\begin{array}{c}10.66 \% \\
(16.19) \\
5.63 \% \\
(9.99)\end{array}$ & $\begin{array}{l}6.24 \% \\
(10.96) \\
15.03 \% \\
(15.31)\end{array}$ & $\begin{array}{l}1 \cdot 52 \% \\
(4 \cdot 63) \\
2 \cdot 21 \% \\
(6 \cdot 49)\end{array}$ & $\begin{array}{l}8 \cdot 24 \% \\
(14 \cdot 22) \\
4 \cdot 29 \% \\
(8 \cdot 09)\end{array}$ & $\begin{array}{l}5 \cdot 10 \% \\
(9 \cdot 53) \\
12 \cdot 05 \% \\
(16 \cdot 28)\end{array}$ & $\begin{array}{l}0.99 \% \\
(2.94) \\
0.98 \% \\
(2 \cdot 32)\end{array}$ \\
\hline
\end{tabular}


Hydro linemen averaged $6.9 \mathrm{kVm}^{-1} \mathrm{~h}$ a day. ${ }^{4}$ Our six "exposed" linesmen averaged only $2 \cdot 10 \mathrm{kVm}^{-1} \mathrm{~h}$ a day, although it should be borne in mind that CEGB staff do not undertake live line work. The Ontario study quotes an average exposure of 12.7 $\mathrm{kVm}^{-1} \mathrm{~h}$ a day for station workers (who would be classed as fitters in the present study) also based on a combined measurement and estimation approach. Our 12 "exposed" fitters averaged $4.04 \mathrm{kVm}^{-1} \mathrm{~h}$ a day with an overall average for fitters (even assuming all the "non-exposed" to be at the detection threshold) of only $1.14 \mathrm{kVm}^{-1} \mathrm{~h}$ a day.

\section{INTERVIEW MEASURES}

In looking for possible effects of exposure attention should be concentrated on the ten main health scores listed in table 4. Five of these (Nos 5-8 and their total No 9) are based on 25 of the original questions in the interview; these questions were modified from the Middlesex Hospital Questionnaire (MHQ) (Crown and Crisp ${ }^{78}$ ). That questionnaire has been shown to give higher scores in people assessed as ill by more thorough medical examination than it does in the general population; it has been slightly modified for use in industrial rather than hospital populations by Broadbent and Gath"; see also Broadbent. ${ }^{10}$ The revised version has again been checked by ourselves against independent examination of a series of patients to make sure that the four scores are related to the assessment that would be given by direct medical interview. The four scores are of anxiety (0-14), depression (0-14), somatic (bodily) symptoms (0-14), and obsessional symptoms (0-8). The questions, as it happens, do not ask about headaches, which are often mentioned in connection with exposure to electric fields; each man was therefore asked to assess his own experience of headaches in the past six months on a scale $0-3$. For completeness, the man was also asked to recall the number of visits to the doctor in the past six months, whether he had taken any medicine on a prescription in the same time (yes/no), and whether he had taken any unprescribed medicine regularly or frequently (yes/no).

Finally noted in table 4 is a measure of cognitive failure-that is, of the frequency of minor episodes of forgetfulness or inattention. This was based on 25 questions, each scored with a maximum of four, so that the score used has a maximum of 100 . This measure was first included in industrial studies as a measure of effects of conditions; but it now seems more likely that it is actually a pre-existing characteristic of the individual that makes him more vulnerable to other conditions." This means that people with high cognitive failure tend to be those who show ill health in other ways when conditions are difficult; but they do not show more cognitive failures in bad rather than in good conditions. The measure has nevertheless been examined in this study as electric fields might have some effect on cognitive failure even if other conditions do not.

Table 4 shows the intercorrelations of the various health measures; many of them are positively correlated-that is, people who report headaches also tend to have high depression scores, and so on. This is particularly true of the MHQ measures, and for many purposes the total MHQ score may be used as a typical measure of ill health.

The fact that the average measures for the whole population are low should also be noted. That is, this group is in general fit rather than unfit. Average scores of less than one on anxiety, depression, and obsessional symptoms are creditable. Table 5 compares the average values of several dependent variables for the current sample with previously obtained corresponding values for samples of car production workers and Health Service manual workers. It will be seen that on every measure the electricity workers show the healthiest score; on every measure the difference from car production

Table 4 Correlations between a number of indices of poor health

\begin{tabular}{|c|c|c|c|c|c|c|c|c|c|c|}
\hline & $\begin{array}{l}10 \\
\text { Cognitive } \\
\text { failure }\end{array}$ & $\begin{array}{l}9 \\
\text { Total } \\
\text { MHQ }\end{array}$ & $\begin{array}{l}8 \\
\text { Depression }\end{array}$ & $\begin{array}{l}7 \\
\text { Somatic } \\
\text { symptoms }\end{array}$ & $\begin{array}{l}6 \\
\text { Obsessional } \\
\text { symptoms }\end{array}$ & 5 Anxiety & ${ }^{4}$ Headaches & $\begin{array}{l}3 \\
\text { Unprescribed } \\
\text { medicines }\end{array}$ & $\begin{array}{l}2 \\
\text { Prescribed } \\
\text { medicines }\end{array}$ & ${ }_{\substack{\text { Doctor } \\
\text { visits }}}^{1}$ \\
\hline 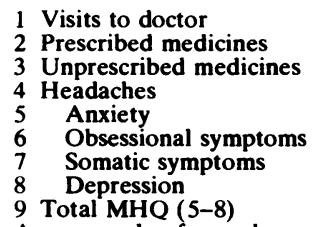 & $\begin{array}{l}0 \cdot 100 \\
0 \cdot 133 \\
0 \cdot 143^{*} \\
0 \cdot 228^{* *} \\
0 \cdot 466^{* *} \\
0 \cdot 433^{* *} \\
0 \cdot 383^{* *} \\
0 \cdot 342^{* *} \\
0 \cdot 481^{* *}\end{array}$ & $\begin{array}{l}0.294^{* *} \\
0.199^{* *} \\
0.145^{*} \\
0.298^{* *} \\
0.882^{* *} \\
0.775^{* *} \\
0.864^{* *} \\
0.838^{* *}\end{array}$ & $\begin{array}{l}0.257^{* *} \\
0.187^{* *} \\
0 \cdot 105 \\
0.291^{* *} \\
0.693^{* *} \\
0.518^{* *} \\
0.632^{* *}\end{array}$ & $\begin{array}{l}0.315^{* *} \\
0.229^{* *} \\
0.100 \\
0.293^{* *} \\
0.648^{* *} \\
0.552^{* *}\end{array}$ & $\begin{array}{l}0.121^{*} \\
0.059 \\
0.136^{*} \\
0.142^{* *} \\
0.612^{* *}\end{array}$ & $\begin{array}{l}0.267^{* *} \\
0.170^{* *} \\
0.150^{*} \\
0.258^{* *}\end{array}$ & $\begin{array}{l}0.196^{* *} \\
0 \cdot 168^{* *} \\
0 \cdot 192^{* *}\end{array}$ & $\begin{array}{l}0.080 \\
0.002\end{array}$ & $0.567^{* *}$ & \\
\hline $\begin{array}{l}\text { Average value for eacn } \\
\text { variable } \\
\text { (Standard deviation) }\end{array}$ & $\begin{array}{c}31.29 \\
(11.03)\end{array}$ & $\begin{array}{l}3.79 \\
(4.86)\end{array}$ & $\begin{array}{l}0.74 \\
(1.30)\end{array}$ & $\begin{array}{l}1.31 \\
(1.72)\end{array}$ & $\begin{array}{l}0.83 \\
(1.20)\end{array}$ & $\begin{array}{l}0.92 \\
(1.53)\end{array}$ & $\begin{array}{l}0.52 \\
(0.71)\end{array}$ & $\begin{array}{l}0.37 \\
(0.48)\end{array}$ & $\begin{array}{l}0.40 \\
(0.49)\end{array}$ & $\begin{array}{l}1 \cdot 10 \\
(1 \cdot 46)\end{array}$ \\
\hline
\end{tabular}

Notice that many are significantly correlated-that is, the same people visit the doctor and also feel depressed or have headaches. Any value above 0.12 indicates a relationship unlikely to be due to chance. ${ }^{*} p<0.05,{ }^{* *} p<0.01$. 
Table 5 Average values of several health indicators for the present and for other samples

\begin{tabular}{llll}
\hline Variable & $\begin{array}{l}\text { Car workers } \\
\text { (all on } \\
\text { production } \\
190 \text { in two } \\
\text { plants) }\end{array}$ & $\begin{array}{l}\text { Health service } \\
\text { manual } \\
\text { workers }(22 \\
\text { in several } \\
\text { South Midlands } \\
\text { hospitals) }\end{array}$ & $\begin{array}{l}\text { Electrical } \\
\text { workers (all } \\
399 \text { interviewed) }\end{array}$ \\
\hline Visits to doctor & $1.41^{*}$ & 1.23 & 1.09 \\
Anxiety & $2 \cdot 28^{* *}$ & $1.68^{* *}$ & 0.95 \\
Somatic symptoms & $2 \cdot 28^{* *}$ & $2.32^{* *}$ & 1.31 \\
Depression & $1.93^{* *}$ & $1.59^{* *}$ & 0.77 \\
Job dissatisfaction & $1.41^{* *}$ & 0.76 & 0.64 \\
Cognitive failure & $35.71^{* *}$ & 32.43 & 31.38 \\
\hline
\end{tabular}

** Difference from electrical workers significant with $p<0.01$.

* Difference significant with $\mathrm{p}<0.05$.

workers is significant, usually enormously so, F being over 30 for the three MHQ scales. On the MHQ scales the differences from the Health Service workers are also significant.

The present study also included several other questions, many of them concerning features of the job itself other than exposure. These yielded 64 scores in all. Most of those featured in the tables or discussed in the text are self explanatory, such as the hours of overtime worked each week in the previous month or the amount of physical work done. One measure that perhaps needs clarification is the degree of discretion in the job; this is the sum of several questions used by Karasek ${ }^{12}{ }^{13}$ which ask the person about the amount of control he exercises over his work. Jobs with high and low discretion are known to differ in various indices of health.

\section{Analyses performed}

In examining relations to measured exposure the actual meter readings, regardless of level, were initially used as the score for each man. As noted earlier, however, readings up to $6.6 \mathrm{kVm}^{-1} \mathrm{~h}$ should probably be regarded as the noise in the measurement system. We shall see evidence later that supports this view. For later analyses, therefore, we divided men into "exposed" and "non-exposed" using this level of $6.6 \mathrm{kVm}^{-1} \mathrm{~h}$ as the cutting point.

The following analyses were carried out.

(a) Product-moment correlations were calculated over the available populations for all the variables concerned-that is, not only the seven exposure indices and the ten main measures of health effects but also the 64 other measures relating to features of the job.

(b) The population for whom measurements were available was then split into those with exposures of $6.6 \mathrm{kVm}^{-1} \mathrm{~h}$ or over ( $\left.28 \mathrm{men}\right)$ and the remainder ( 259 men), and the two groups were compared on the average value for each of the other 80 variables.
This was because of the possibility that differences in measured exposure might at the lower levels be simply random error. For the same reason, the correlation matrix of $(a)$ was recalculated for the 28 exposed men alone.

(c) Because job and geographical district appeared to be related to exposure, the men were divided according to the five categories of job and the three geographical districts. Within each of the 15 cells thus formed the exposed men were separated from the non-exposed. A three way analysis of variance was then performed, separating the effects of exposure, district, and job and correcting each for the effects of the other two (SPSS "classic" approach, options 7 or 8). ${ }^{14}$ The dependent measures examined in this way were total MHQ, each of the subscales, cognitive failure, job dissatisfaction (scale 0-3), headaches, personal problems (0-2), and the taking of unprescribed medicine.

These analyses examine effect of exposure corrected for job and district. It could be argued, however, that the main effects should be corrected for interactions (changes in the size of one effect in the presence of another). Analyses were therefore performed using this technique (SPSS option 9) ${ }^{14}$ for total MHQ, cognitive failure, and job dissatisfaction.

(d) As a further precaution, two way analyses of variance were conducted extracting only jobs or only districts, thus decreasing the number of empty cells. Correlations between exposure indices and the dependent measures were also calculated separately for each geographical area. Lastly, the mean scores in each of the job/district cells were correlated with other features of that cell, such as the hours of work and the number of recent changes of shift.

\section{Results}

\section{OVERALL CORRELATIONS}

Table 6 shows the correlations of each of the dependent measures with the exposure measures for the whole study population. It can be seen at once that this table shows no significant correlations with the recorded exposure readings.

Relations with the estimated exposures are also predominantly negligible, only six of the 60 correlations being statistically significant. Furthermore, three of these are in the direction of more exposed men having fewer symptoms. The three positive ones are the correlation of frequency of visits to the doctor with estimated 15 year exposure to low fields, and of taking unprescribed medicine with estimated six month and 15 year exposures to low fields, the relationships reversing for medium and high fields. As we shall see later, the most plausible explanation 
Table 6 Correlations between measured and estimated exposures and each of the indices of poor health for all available respondents

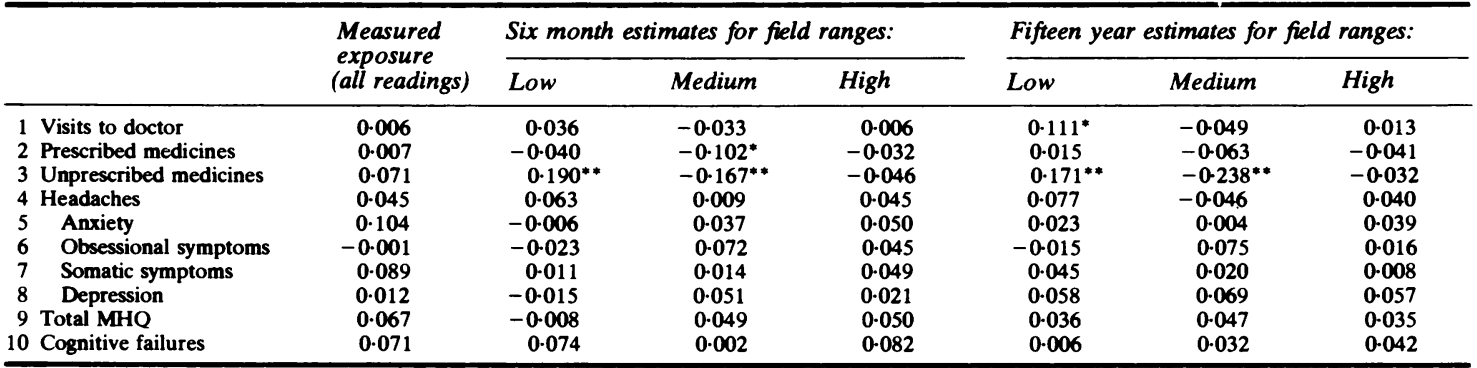

A significant result would be detected if the value reached 0.138 for the measurements and 0.1 for the estimates-that is $1 \%$ of variance. ${ }^{*} \mathrm{p}<0.05,{ }^{* *} \mathrm{p}<0.01$.

Table 7 Some examples of significant correlations with indices of poor health that do appear

\begin{tabular}{|c|c|c|c|c|c|c|}
\hline & & $\begin{array}{l}\text { Reported personal } \\
\text { problems }\end{array}$ & $\begin{array}{l}\text { Time working } \\
\text { alone }\end{array}$ & $\begin{array}{l}\text { Amount of recent } \\
\text { overtime }\end{array}$ & $\begin{array}{l}\text { No of recent shift } \\
\text { changest }\end{array}$ & $\begin{array}{l}\text { Inability to correct } \\
\text { mistakes }\end{array}$ \\
\hline \multirow{9}{*}{$\begin{array}{r}1 \\
2 \\
3 \\
4 \\
5 \\
6 \\
7 \\
8 \\
9 \\
10\end{array}$} & 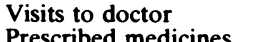 & $0 \cdot 151^{*}$ & - & 二 & - & 二 \\
\hline & $\begin{array}{l}\text { Prescribed medicines } \\
\text { Unprescribed medicines }\end{array}$ & $\frac{0.117^{*}}{-}$ & 二 & $0 \cdot 198^{* *}$ & - & $\overline{0.211^{*}}$ \\
\hline & Headaches & $0 \cdot 168^{* *}$ & - & - & - & - \\
\hline & Anxiety & $0 \cdot 183^{* *}$ & - & - & $0.427^{*}$ & $0 \cdot 132^{*}$ \\
\hline & Obsessional symptoms & $\overline{0}$ & $\overline{0}$ & - & $0 \cdot 379^{*}$ & - \\
\hline & Somatic symptoms & $0.118^{*}$ & $0 \cdot 123^{*}$ & - & - & - \\
\hline & Depression & $0.232^{* *}$ & & - & $0.421^{*}$ & - \\
\hline & Total MHQ & $0.185^{* *}$ & $0 \cdot 122^{*}$ & - & $0.419^{*}$ & $\overline{0}$ \\
\hline & Cognitive failures & - & - & - & - & $0 \cdot 132^{*}$ \\
\hline
\end{tabular}

${ }^{*} \mathrm{p}<0.05,{ }^{* *} \mathrm{p}<0.01$

†For the 33 shift workers only.

of these paradoxical relationships is that exposure differs in different jobs; we would not argue that exposure to electric fields makes people healthier.

As some indication of the sensitivity of the study, table 7 shows a few of the factors that did appear to be significantly correlated with some of the health indices. As can be seen, associations were picked up with such factors as personal problems, working alone rather than in company, or (particularly) working long hours and having recently changed shift.

In addition to the ten main health indices presented all other available variables were examined for possible relations with measured or estimated exposure. The only ones showing some correlation were those characterising the job itself. Thus, for instance, no correlations with number of male children, use of leisure, or anything of that sort were significant. Estimated exposure was, however, correlated with the amount of physical work in the job, with absence of discretion in the way it was done, with inability to control the duration of restbreaks, and so on. The people who were thought to receive exposure had very different work from the others.

A point requiring particular attention is that measured and estimated exposures did not correlate well with each other; not one of the six estimates was significantly correlated with the actual exposure readings. As the distribution of exposure readings was heavily skewed, product-moment correlations are suspect. Furthermore, it was thought that much of the variation in those measurements less than $6 \cdot 6$ $\mathrm{kVm}^{-1} \mathrm{~h}$ was attributable to noise and only readings above that value were truly due to exposure. Accordingly, we proceeded to the second analysis.

\section{COMPARISON OF EXPOSED AND NON-EXPOSED} GROUPS

When the correlation analysis was repeated on the exposed men only, no special fresh findings emerged, apart from a single significant positive correlation between estimated 15 year exposure to high fields and frequency of visits to the doctor (see table 8).

Nevertheless, the separation into two sharply distinct groups did indeed find several factors to be different for the exposed and non-exposed men and these are shown in table 9 . The exposed men do jobs with greater physical work, travel more, have less to remember, and normally do less overtime. The difference in estimated recent exposure is particularly satisfactory because it increases confidence in both 
Table 8 As for table 6, but restricted to the 28 (26 for estimates) subjects whose exposure measurements were above the detection threshold of $6.6 \mathrm{kVm}-\mathrm{h}$

\begin{tabular}{|c|c|c|c|c|c|c|c|}
\hline & \multirow{2}{*}{$\begin{array}{l}\text { Measured } \\
\text { exposure } \\
\text { (above noise } \\
\text { only) }\end{array}$} & \multicolumn{3}{|c|}{ Six month estimates for field ranges: } & \multicolumn{3}{|c|}{ Fifteen year estimates for field ranges: } \\
\hline & & Low & Medium & High & Low & Medium & High \\
\hline $\begin{aligned} 1 & \text { Visits to doctor } \\
2 & \text { Prescribed medicines } \\
3 & \text { Unprescribed medicines } \\
4 & \text { Headaches } \\
5 & \text { Anxiety } \\
6 & \text { Obsessional symptoms } \\
7 & \text { Somatic symptoms } \\
8 & \text { Depression } \\
9 & \text { Total MHQ } \\
10 & \text { Cognitive failures }\end{aligned}$ & $\begin{array}{r}0.090 \\
0.117 \\
0.241 \\
0.233 \\
0.155 \\
-0.119 \\
0.143 \\
-0.045 \\
0.049 \\
0.093\end{array}$ & $\begin{array}{r}0.146 \\
0.268 \\
0.026 \\
0.140 \\
-0.098 \\
0.120 \\
0.005 \\
0.030 \\
0.031 \\
0.124\end{array}$ & $\begin{array}{r}-0.110 \\
-0.054 \\
-0.425^{*} \\
-0.183 \\
-0.089 \\
-0.005 \\
-0.025 \\
0.036 \\
-0.027 \\
-0.134\end{array}$ & $\begin{array}{r}0.323 \\
0.275 \\
-0.110 \\
-0.056 \\
-0.009 \\
0.075 \\
0.149 \\
0.103 \\
0.085 \\
0.047\end{array}$ & $\begin{array}{r}0.236 \\
0.359 \\
0.039 \\
0.136 \\
-0.111 \\
0.228 \\
0.097 \\
0.048 \\
0.063 \\
0.186\end{array}$ & $\begin{array}{c}0.032 \\
0.091 \\
-0.474^{*} \\
-0.058 \\
-0.120 \\
-0.016 \\
0.040 \\
0.019 \\
-0.024 \\
-0.163\end{array}$ & $\begin{array}{r}0.392^{*} \\
0.324 \\
-0.196 \\
-0.091 \\
-0.070 \\
-0.053 \\
0.058 \\
0.099 \\
0.007 \\
-0.102\end{array}$ \\
\hline
\end{tabular}

A significant result for this smaller sample requires a correlation coefficient greater than 0.39 .

${ }^{*} \mathrm{p}<0.05,{ }^{* *} \mathrm{p}<0.01$.

Table 9 Some differences in average values of measures for the exposed $\left(>6.6 \mathrm{kVm}^{-1} \mathrm{~h}\right)$ and non-exposed groups

\begin{tabular}{|c|c|c|c|}
\hline Variable & $\begin{array}{l}\text { Measure of } \\
28 \text { exposed }\end{array}$ & $\begin{array}{l}\text { Measure of } \\
259 \\
\text { non-exposed }\end{array}$ & Significance \\
\hline \multirow{2}{*}{$\begin{array}{l}\text { Amount of physical } \\
\text { work } \\
\text { No of shift changes } \\
\text { in past } 3 \text { days }\end{array}$} & 1.43 & 0.92 & $p<0.01$ \\
\hline & 1.67 & 0.87 & $\begin{array}{l}\text { Insignificant } \\
\text { (only } 33 \text { men } \\
\text { doing shift work) }\end{array}$ \\
\hline \multirow{2}{*}{$\begin{array}{l}\text { Amount of time spent } \\
\text { travelling } \\
\text { Proportion saying they } \\
\text { often work } \\
\text { overtime }\end{array}$} & 1.68 & $1 \cdot 35$ & $p<0.05$ \\
\hline & $y^{0 \cdot 18}$ & 0.41 & $p<0.05$ \\
\hline \multirow[t]{2}{*}{$\begin{array}{l}\text { Amount and variability } \\
\text { of what has to be } \\
\text { remembered } \\
\text { Total MHQ }\end{array}$} & $\begin{array}{l}1 \cdot 00 \\
4 \cdot 89\end{array}$ & $\begin{array}{l}1 \cdot 31 \\
3 \cdot 67\end{array}$ & $\begin{array}{l}\mathrm{p}<0.05 \\
\text { Insignificant } \\
\text { (difference } \\
\text { would need to } \\
\text { be } 1.89 \text { for } \\
\text { significance) }\end{array}$ \\
\hline & $\begin{array}{l}\text { Measure of } \\
26 \text { exposed }\end{array}$ & $\begin{array}{l}\text { Measure of } \\
253 \\
\text { non-exposed }\end{array}$ & \\
\hline $\begin{array}{l}6 \text { months estimated } \\
\text { exposure to medium } \\
\text { fields }\end{array}$ & $15 \cdot 03$ & $5 \cdot 43$ & $p<0.05$ \\
\hline
\end{tabular}

the estimates and the measurements.

The appearance of these significant differences once we separate out those with definite measured exposure is possibly due to the skewness of the distribution of actual meter readings and it lends weight to the argument that the lower readings are largely spurious. The difference in total MHQ scores between the two groups, however, is numerically only about two thirds the size necessary to achieve significance. Therefore, although we have a clear difference in the types of job done by the exposed men, there are no definite indications about their health and there is a need for further analyses.

As we shall see later, these analyses will make us conclude that there is no evidence for effects of exposure on health; the insignificant difference in MHQ scores between exposed and non-exposed is accounted for by differences in job and district. Before drawing a negative conclusion, however, it is proper to explore the devil's advocate hypothesis that some contaminating factor is concealing an effect of exposure. One such factor might itself be the nature of the job done by an individual. If, for instance, exposed workers were in jobs that were in other ways healthier, that might explain the absence of overall effects on health.

\section{DIVISION OF SAMPLE BY DISTRICT AND JOB}

In fact, the number of people exposed is related to the category of job they do and to the district they come from ( $p<0.01$ in each case) and this confirms the differences in job related factors found already. Therefore, we proceeded to split up the sample by job and by district, amalgamating the adjacent CEGB Severn and Thames districts to maintain adequate numbers in each of the 15 resulting subdivisions, which are shown in table 10 , together with the mean total MHQ score for each cell.

When the numbers of cases in each cell are unequal, as in these data, there are several possible methods of analysis. Each makes slightly different assumptions and these assumptions are debatable. For example, should one test the effect of factor $A$ only after eliminating that of factor $B$, or should one correct each for the other? We thought it best, therefore, to try several of the most plausible options, so that the conclusion would not rest on any particular assumption. In the first instance, analysis of variance was carried out correcting the effects of exposure, district, and job each for the effects of the other. The resulting $F$ values are given in table 11 .

It is immediately obvious that there are major differences between districts; of the ten measures shown, all but one (the number of personal prob- 
Table 10 Numbers of exposed $\left(>6.6 \mathrm{kVm}^{-1} \mathrm{~h}\right)$ and non-exposed subjects in various jobs and districts, together with the average $M H Q$ score for each group

\begin{tabular}{|c|c|c|c|c|c|c|c|c|c|c|c|c|c|}
\hline & & \multicolumn{2}{|c|}{$\begin{array}{l}\text { Substation } \\
\text { attendants }\end{array}$} & \multicolumn{2}{|c|}{ Fitters } & \multicolumn{2}{|c|}{ Engineers } & \multicolumn{2}{|c|}{ Linesmen } & \multicolumn{2}{|c|}{ Others } & \multicolumn{2}{|c|}{ Totals } \\
\hline & & & $M H Q$ & No & $M H Q$ & No & $M H Q$ & No & $M H Q$ & No & $M H Q$ & No & $M H Q$ \\
\hline South Wales & $\begin{array}{l}\text { Exposed } \\
\text { Non-exposed }\end{array}$ & $\begin{array}{l}3 \\
3\end{array}$ & $\begin{array}{l}17 \cdot 67 \\
10.00\end{array}$ & $\begin{array}{l}4 \\
6\end{array}$ & $\begin{array}{l}5 \cdot 75 \\
8 \cdot 83\end{array}$ & $\begin{array}{r}1 \\
14\end{array}$ & $\begin{array}{l}1.00 \\
5 \cdot 29\end{array}$ & $\begin{array}{l}2 \\
3\end{array}$ & $\begin{array}{l}9 \cdot 50 \\
8 \cdot 00\end{array}$ & $\begin{array}{r}3 \\
11\end{array}$ & $\begin{array}{l}3.67 \\
5.82\end{array}$ & $\begin{array}{l}13 \\
37\end{array}$ & $\begin{array}{l}8 \cdot 23 \\
6 \cdot 62\end{array}$ \\
\hline $\begin{array}{l}\text { Severn and } \\
\text { Thames }\end{array}$ & $\begin{array}{l}\text { Exposed } \\
\text { Non-exposed }\end{array}$ & $\begin{array}{r}2 \\
24\end{array}$ & $\begin{array}{l}1 \cdot 50 \\
4 \cdot 00\end{array}$ & $\begin{array}{r}8 \\
27\end{array}$ & $\begin{array}{l}3.25 \\
3 \cdot 59\end{array}$ & $\begin{array}{r}\mathbf{0} \\
\mathbf{3 2}\end{array}$ & $\overline{2 \cdot 63}$ & $\begin{array}{l}3 \\
6\end{array}$ & $\begin{array}{l}0.00 \\
1.50\end{array}$ & $\begin{array}{r}0 \\
14\end{array}$ & $\overline{2 \cdot 50}$ & $\begin{array}{r}13 \\
103\end{array}$ & $\begin{array}{l}2 \cdot 23 \\
3 \cdot 12\end{array}$ \\
\hline SWaEB & $\begin{array}{l}\text { Exposed } \\
\text { Non-exposed }\end{array}$ & $\begin{array}{l}0 \\
4\end{array}$ & -3.00 & $\begin{array}{l}0 \\
39\end{array}$ & $\overline{3 \cdot 82}$ & $\begin{array}{r}1 \\
15\end{array}$ & $\begin{array}{l}0.00 \\
3.27\end{array}$ & $\begin{array}{r}1 \\
15\end{array}$ & $\begin{array}{l}1 \cdot 00 \\
4 \cdot 47\end{array}$ & $\begin{array}{r}0 \\
46\end{array}$ & $\overline{2 \cdot 35}$ & $\begin{array}{r}2 \\
119\end{array}$ & $\begin{array}{l}0.50 \\
3 \cdot 23\end{array}$ \\
\hline
\end{tabular}

The proportion of exposed men is significantly different between districts and between jobs. Note that in most cases the MHQ score indicates poorer health for the non-exposed group.

Table $11 F$ values for effects of exposure, district, and job, each corrected for the other but not for interactions

\begin{tabular}{|c|c|c|c|}
\hline $\begin{array}{l}\text { Factors } \\
\text { Degrees of freedom }\end{array}$ & $\begin{array}{l}\text { Measured exposure } \\
1 \text { and } 262\end{array}$ & $\begin{array}{l}\text { District } \\
2 \text { and } 262\end{array}$ & $\begin{array}{l}\text { Job } \\
4 \text { and } 262\end{array}$ \\
\hline $\begin{aligned} 1 & \text { Job dissatisfaction } \\
2 & \text { Personal problems } \\
3 & \text { Unprescribed medicines } \\
4 & \text { Headaches } \\
5 & \text { Anxiety } \\
6 & \text { Obsessional symptoms } \\
7 & \text { Somatic symptoms } \\
8 & \text { Depression } \\
9 & \text { Total MHQ } \\
10 & \text { Cognitive failure }\end{aligned}$ & $\begin{array}{l}0.818 \text { (NB) } \\
0.244 \\
0.341 \text { (NB) } \\
0.715(\mathrm{NB}) \\
0.024(\mathrm{NB}) \\
0.074 \\
0.905(\mathrm{NB}) \\
0.549(\mathrm{NB}) \\
0.278(\mathrm{NB}) \\
0.377\end{array}$ & $\begin{array}{c}11 \cdot 420^{* *} \\
1 \cdot 316 \\
39 \cdot 484^{* *} \\
4 \cdot 326^{*} \\
7 \cdot 696^{* *} \\
10.487^{* *} \\
13 \cdot 729^{* *} \\
16 \cdot 140^{* *} \\
16 \cdot 927^{* *} \\
3 \cdot 960^{*}\end{array}$ & $\begin{array}{l}0.782 \\
0.156 \\
1.055 \\
2.252 \\
1.979 \\
1.706 \\
2.530^{*} \\
3.364^{* *} \\
3.003^{*} \\
1.822\end{array}$ \\
\hline
\end{tabular}

* $p<0.05 ;{ }^{* *} p<0.01$.

(NB) indicates corrected means differ by exposed group having lower mean. Job dissatisfaction and personal problems have been given, rather than visits to doctor and prescribed medicine as in other tables, because the latter measures showed no effect of any factor.

lems) give significant effects. In each case the CEGB South Wales district is, in fact, the highest; possible reasons will appear later. Differences between jobs are also prominent; two of the MHQ measures and the total MHQ score give significant differences, the substation assistants and fitters having the most symptoms and the "others" the least.

If we now turn to the effects of measured exposure, however, we find that not one of the ten variables shows a significant difference. Furthermore, the correction has actually reversed the difference between exposed and non-exposed in the uncorrected means for total MHQ (table 9) and for certain other scores. Thus it is not merely that these differences fail to reach the level of significance; numerically, they are in the direction of greater health for exposed men. Because of the dependence of corrected means on the exact assumptions used in their calculations, they are not shown in table 11; but the measures are marked that give reversed differences when corrected.

\section{EXTRA PRECAUTIONARY ANALYSES}

The analyses of variance based on different assumptions, and the two way analyses, all came to the same conclusion as the main ones. Similarly, correlating the exposure indices (both measurements and estimates) with the dependent measures separately within each district required no change in the negative conclusions reached over the whole sample. Correlating mean MHQ in a job/district cell with other properties of that cell showed that the exposed men tended to come from cells which seemed to have poor health in general; the proportion of exposure in a cell correlated not only with the mean MHQ of the exposed men (tau $=0.66)$, but also with that of the non-exposed men $(\operatorname{tau}=0 \cdot 56)$. We therefore considered the hypothesis that in those cells there might be some exposure that was not shown either by estimate or by measurement in one sample of two weeks; however, there seems no need to believe this, because those cells are also high in other factors that are known to impair health. For example, the mean MHQ of the non-exposed men in a cell is correlated (tau $=0.52$ ) with a measure of the abnormal overtime that has been worked in that cell in the past month. It seems in fact that exposure is tending to occur in job/district combinations where operational problems are causing extra load on the staff, and this is reflected in the MHQ scores even of the non-exposed men.

\section{Conclusions}

We have found no evidence in the transmission and distribution staff studied for health effects of occu- 
pational exposure to electric fields, whether measured or estimated. Naturally some caution must be used in drawing inferences from this result. Firstly, it may be that there is an effect of electric fields, but that it is on some aspect of health we have not studied. Secondly, it is conceivable that there could be an effect at higher levels of exposure. Thirdly, it is possible that there is an effect only on certain vulnerable individuals or in the presence of some factor such as outside stress, which is reversed in other individuals or conditions. (We have noted that our sample is a relatively healthy one.)

Nevertheless, the present study has been sensitive enough to show clear health differences between job categories and geographical districts. It has also detected the effects of working alone, working long hours, and, particularly, of having changed shift several times in the past three days. The fact that such aspects of the job may be associated with poor health provides one possible explanation for the original observations from the Soviet Union that workers in high voltage substations have poor health. If jobs with exposure mean working long hours, shift work, or working alone, or a combination of these one might well detect symptoms in the people concerned. The present data associate ill health with the other features of the job, not with the degree of exposure.

This research depended on the willing cooperation and effort of many members of CEGB staff, both those interviewed and those organising and helping the inquiry. Thanks are due to all of them, but especially to Alice Gillett, Susan Lorman, and Elizabeth Westall who undertook much of the actual interviewing with Margaret Jones. We also gratefully acknowledge the extensive help and advice given by numerous colleagues, including $\mathbf{J}$ A Bonnell, $P$ F Chester, R H Minors, W T Norris, A E T Nye, C J Stringfellow, and $M$ W Watts.
Requests for reprints to: Dr D E Broadbent.

\section{References}

' Korobkova VP, Morozov YA, Stolarov MS, Yakub YA. Influence of the electric field in 500 and $750 \mathrm{kV}$ switchyards on maintenance staff and means for its protection. Conference Internationale des Grands Reseaux Electrique a Haute Tension 1972;23-6.

${ }^{2}$ Malboysson E. Medical control of men working within electromagnetic fields. Revue Generale de l'Electricité 1976;75-80.

${ }^{3}$ Roberge PF. Study on the state of health of electrical maintenance workers on Hydro-Quebec's $735 \mathrm{kV}$ power transmission system. Montreal: Hydro-Quebec, 1976.

${ }^{4}$ Stopps CJ, Janischewskyj W. Epidemiological study of workers maintaining $H V$ equipment and transmission lines in Ontario. Montreal: Canadian Electrical Association, 1979.

${ }^{5}$ Knave B, Gamberdale F, Bergstrom S, et al. Long-term exposure to electric fields-a cross-sectional epidemiologic investigation of occupationally exposed workers in high-voltage substations. Electra 1979;65:41-54.

- Deno DW. Currents induced in the human body by high voltage transmission line electric fields. IEEE Trans Power Apparatus and Systems 1977;96:1517-27.

${ }^{7}$ Crown S, Crisp AH. A short clinical diagnostic self-rating scale for psycho-neurotic patients. Br J Psychiatry 1966;112:91723.

${ }^{8}$ Crown S, Crisp AH. Manual of the Crown-Crisp experiential index. London: Hodder and Stoughton, 1979.

${ }^{9}$ Broadbent DE, Gath D. Chronic effects of repetitive and nonrepetitive work. In: Mackay C, Cox T, eds. Response to stress. London: IPC, 1979:120-8.

${ }^{10}$ Broadbent DE. Chronic effects from the physical nature of work. In: Gardell B, Johansson C, eds. Working life. New York: Wiley, 1981:39-51.

" Broadbent DE, Cooper PF, FitzGerald P, Parkes KR. The cognitive failures questionnaire (CFQ) and its correlates. $\mathrm{Br} \mathrm{J} \mathrm{Clin}$ Psychol 1982;21:1-16.

${ }^{12}$ Karasek, RA. Job demands, job decision latitude, and mental strain: implications for job redesign. Administrative Science Quarterly, 1979;24:285-308.

${ }^{13}$ Karasek RA. Job socialisation and job strain. The implication of two related psychosocial mechanisms for job design. In: Gardell B, Johansson G, eds. Working life. New York: Wiley, 1981:75-94.

14 Nie NH. SPSS: statistical package for the social sciences. 2nd ed. New York: McGraw Hill, 1975. 
Ergonomics and Health in Modern Offices $E$ Grandjean, ed. (Pp 510, £35.00.) London; Taylor and Francis, 1984.

This collection of papers presented at the Turin Conference on Ergonomic and Health Aspects in Modern Offices in 1983 highlights the fact that office life is becoming increasingly technical and complicated. Traditional ergonomic checklists are inadequate to cope with the trend towards multifunctional office spaces housing a vast array of electronic equipment such as visual display terminals, microfiche readers, laser printers, and photocopying machines. In many offices environmental problems related to some "traditional" factors, such as noise, lighting, heat, and cold are still present and in some cases are increasing side by side with the introduction of new technologies and new forms of work organisation.

The 510 page book comprises some 76 papers, aspects of using visual display units predominating, with an excellent section on ophthalmology in consideration of the contentious topic of visual "fitness" for visual display unit operators. Also covered are conclusions concerning visual, musculoskeletal, pregnancy, dermatological, neurological, and stress problems suspected of affecting visual display unit operators in relation to work organisation, environment, and equipment design hazards.

Of toxicological interest is reference to the effects of sealed office buildings to conserve energy, the so termed "building illness" syndrome that appears to emanate from these conditions. Papers covering the quality of indoor air in offices include reference to allergies caused by sources of biological contaminants such as humidifiers, and health risks caused by pollutants such as tobacco smoke, building and furniture materials, insulating boards, solvents used for cleaning, photocopying equipment, and photochemical "smog" formations. Altogether a stimulating book and a useful source of reference material for anyone dealing with this challenging field of occupational health, which is newly emerging as seeking increased attention.

J CONYERS
Biological Monitoring and Surveillance of Workers Exposed to Chemicals. Edited by A Aitio, V Riihimaki, and H Vainio. (£64.00.) New York: Hemisphere Publishing Corporation, 1984.

These papers were presented at an international course on biological monitoring of exposures to industrial chemicals that was held in Helsinki in 1980. It is astonishing that it has taken four years to see the light of day, especially as the bulk of the text has been prepared photographically from typescript. There are 33 contributors, all but three of whom hail from Scandinavia, and this has led to a certain unevenness in both style and content.

Many of the chapters reiterate what may be found in dozens of other books - there is little new to say about most of the toxic metals or about the solvents-but several chapters deal with topics that will be unfamiliar with many occupational health practitioners (or at least, they would have been in 1980!). Those which deal with solvent interactions, with urinary thioether excretion, with the excretion of mutagenic substances in the urine, haemoglobin alkylation, and chromosomal aberrations are all valuable. In general, however, the editors have allowed the authors to stray too far from their brief,and several have used the opportunity to present a (presumably unrefereed) version of their own work.

What I looked for and did not find in this book was any guidance on biological monitoring. Scarcely any of the authors say what should be done as the result of all the monitoring and surveillance which is to be carried out, and where is the reference to action levels? Anyone coming to this book in the hope that he will be given clear or concise information on how to monitor a hazard in the workplace will be greatly disappointed. With the present parlous state of the pound, this book will cost well over $£ 50$ and at that price I regret that I am unable to recommend it.

H A WALDRON

\section{Correction}

\section{Health of workers exposed to electric fields (February 1985)}

The last sentence on page 75 should read " On interrogation at the end of the period, it gave a single measure of integrated exposure to all field strengths above about 60 volts per metre." 